Article

\title{
Impact of a Synthetic Component on the Emission of Volatile Organic Compounds during the Combustion Process in a Miniature Turbine Engine
}

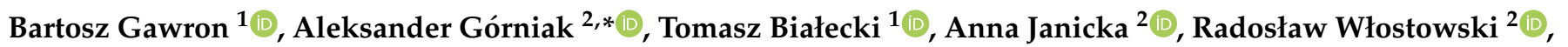 \\ Adriana Włóka ${ }^{2}$, Justyna Molska ${ }^{2}$ and Maciej Zawiślak ${ }^{2}$ \\ 1 Fuels and Lubricants Division, Air Force Institute of Technology, 01-494 Warsaw, Poland; \\ bartosz.gawron@itwl.pl (B.G.); tomasz.bialecki@itwl.pl (T.B.) \\ 2 Division of Automotive Engineering, Faculty of Mechanical Engineering, Wroclaw University of Science and \\ Technology, Wyb. Wyspianskiego 27, 50-370 Wroclaw, Poland; anna.janicka@pwr.edu.pl (A.J.); \\ radoslaw.wlostowski@pwr.edu.pl (R.W.); adriana.wloka@pwr.edu.pl (A.W.); \\ justyna.molska@pwr.edu.pl (J.M.); maciej.zawislak@pwr.edu.pl (M.Z.) \\ * Correspondence: aleksander.gorniak@pwr.edu.pl; Tel.: +48-71-340-79-18
}

Citation: Gawron, B.; Górniak, A.; Białecki, T.; Janicka, A.; Włostowski, R.; Włóka, A.; Molska, J.; Zawiślak, M. Impact of a Synthetic Component on the Emission of Volatile Organic Compounds during the Combustion Process in a Miniature Turbine Engine. Energies 2021, 14, 8462. https://doi.org/ $10.3390 /$ en14248462

Academic Editors: Jesper Schramm and David Chiaramonti

Received: 28 October 2021

Accepted: 10 December 2021

Published: 15 December 2021

Publisher's Note: MDPI stays neutral with regard to jurisdictional claims in published maps and institutional affiliations.

Copyright: (c) 2021 by the authors. Licensee MDPI, Basel, Switzerland. This article is an open access article distributed under the terms and conditions of the Creative Commons Attribution (CC BY) license (https:// creativecommons.org/licenses/by/ $4.0 /)$.
Abstract: This paper refers to the study of biofuel as an alternative power source for turbine aviation engines. Blends of Jet A-1 fuel and synthesized hydrocarbons from Hydrotreated Esters and Fatty Acids (HEFA) technology at different proportions, such as $25 \%, 50 \%$ and $75 \%$, were used for tests. All the test results were compared with the neat Jet A-1 fuel. A miniature GTM series turbojet engine was used in the test rig studies. During the tests conducted at a specific rotational speed, selected engine operating parameters as well as the emission of volatile organic compounds were measured. In terms of engine performance, no significant differences were found between the test fuels. The results of volatile organic compound emissions indicate that among the most toxic compounds the highest concentrations were obtained for benzene. The addition of the HEFA synthetic component and increasing its proportion in the blend resulted in the obtained concentration values for benzene showing a decreasing trend. The plotted utility profile indicates that the most optimal blend, i.e., the least toxic, is the blend with the share $(v / v)$ of $62.5 \%$ of Jet A-1 fuel and $37.5 \%$ of HEFA component.

Keywords: synthetic jet fuels; turbine engine; combustion process; exhaust emissions; volatile organic compounds

\section{Introduction}

In the last 10 years, the need to reduce carbon dioxide $\left(\mathrm{CO}_{2}\right)$ emissions has emerged in the aviation industry. One of the main directions that allow for the reduction of these emissions is the introduction of alternative power sources for the turbine engines that power modern aircraft. New fuels, especially the so-called 'drop-in' fuel, play an important role in this area. The 'drop-in' fuel is a fuel consisting of a blend of petroleum jet fuel with synthetic blending component, without the need to modify the aircraft power systems.

Currently, the standard [1] allows for the use in turbine aviation engines of seven technologies for the production of synthetic hydrocarbons as components for blending with fossil jet fuel. The maximum percentage of the synthetic component in the blend, depending on the technology, does not exceed $50 \%$.

The European Commission Directive states that a volatile organic compound is any organic compound having a boiling point lower or equal to $250^{\circ} \mathrm{C}$, measured at a standard pressure of $1013 \mathrm{hPa}$ [2]. Volatile organic compounds (VOCs) are involved in photochemical reactions that produce harmful and toxic products. VOCs may cause serious health effects such as: headaches and dizziness, drowsiness, irritation of mucous membranes, permanent liver or nervous system damage. Many VOCs exhibit toxic, carcinogenic, mutagenic or neurotoxic properties. In addition, many of them produce odours and thus contribute to 
the deterioration of human living conditions. VOCs enter the body through the respiratory system, the digestive system and through the skin. They are listed as the second most harmful air pollutant after nitrogen oxide $\left(\mathrm{NO}_{\mathrm{x}}\right)$ [3].

VOCs include many groups of compounds, the most numerous of which are:

- $\quad$ aliphatic hydrocarbons (e.g., ethane, ethylene);

- $\quad$ ring hydrocarbons (cycloalkanes);

- $\quad$ aromatic hydrocarbons (e.g., benzene, toluene, xylenes);

- halogenated hydrocarbons (e.g., chloromethane);

- $\quad$ nitrated hydrocarbons (e.g., nitrobenzene);

- alcohols and phenols (e.g., methanol, ethanol);

- carbonyl derivatives (e.g., acrolein, acetone);

- carboxylic acids and esters (e.g., formic acid, acetic acid);

- heterocyclic organic compounds containing inter alia nitrogen, oxygen, sulphur; most of them are the so-called odours,

- aliphatic sulphur compounds (odours);

- aliphatic amines (odours);

- $\quad$ aromatic amines (e.g., aniline).

Within the group of VOCs, compounds from the BTX group deserve special attention. These are aromatic hydrocarbons such as benzene, toluene and xylenes. Their highest concentrations can be observed along traffic routes. The most toxic one is benzene- the simplest aromatic hydrocarbon, volatile, fragrant, flammable, lighter than water and insoluble in it. Benzene enters the body mainly through the respiratory tract and the skin. It has strong carcinogenic, mutagenic, teratogenic and embryotoxic properties. After ingestion, it causes nausea and vomiting. Acute poisoning may lead to death, preceded by convulsions, arrhythmia or respiratory distress [4]. Benzene occurs naturally in crude oil and coal tar. Benzene in atmospheric air comes partly from evaporation of fuels at petrol stations and fuel depots, as well as from technological processes that use organic solvents and in coking and petrochemical processes. Internal combustion engines are the main source of BTX. In addition, it is estimated that emissions associated with fuel evaporation account for $30-50 \%$ of total BTX emissions from vehicles [5].

In the literature, there are articles concerning the research on the emission of volatile organic compounds carried out on aviation turbine engines [6-9]. However, it is worth mentioning that these papers discuss the tests conducted on turbine engines in full scale. An interesting solution may be to carry out tests of alternative fuels for aviation on turbine engines in small scale, which may constitute a preliminary verification of a new fuel before starting tests on larger engines. In the literature, there are numerous papers of different nature on small-scale turbine engines. A few selected items published only in 2020-2021 are included in [10-13].

It is worth mentioning that generally articles describing tests of alternative fuels on small scale turbine engines concern the assessment of fuel influence on the performance and exhaust emissions, mainly regarding gaseous components of exhaust gases and particulates. There is a lack of studies using a small-scale turbine engine for assessment of exhaust gas toxicity, including emissions of volatile organic compounds.

The cooperation between the authors of this paper has already resulted in several publications [14-17], precisely on the assessment of toxicity of exhaust gases emitted during operation of a miniature jet engine powered by various fuels. Papers [14-16] concern toxicity assessment using the BAT-CELL method, which consists of determination of virtual toxic impact of the gas mixture on the living cells. Paper [17] presents the results of studies on the emission of volatile organic compounds (including benzene, toluene) of petroleum fuel with $25 \%$ of biobutanol.

The aim of this study is the emission characteristic of volatile organic compounds of a miniature turbojet engine fed with blends of Jet A-1 and HEFA synthetic component. The results obtained for blends were compared with results for neat Jet A-1. 


\section{Materials and Methods}

A schematic diagram of the test rig, in which the dynamometer tests were carried out, is presented in Figure 1. The essential element of the rig was a miniature GTM-140 turbojet engine, whose purpose was to generate gases as a result of the process of combustion of test fuels. The gas turbine specification are presented in Table 1.

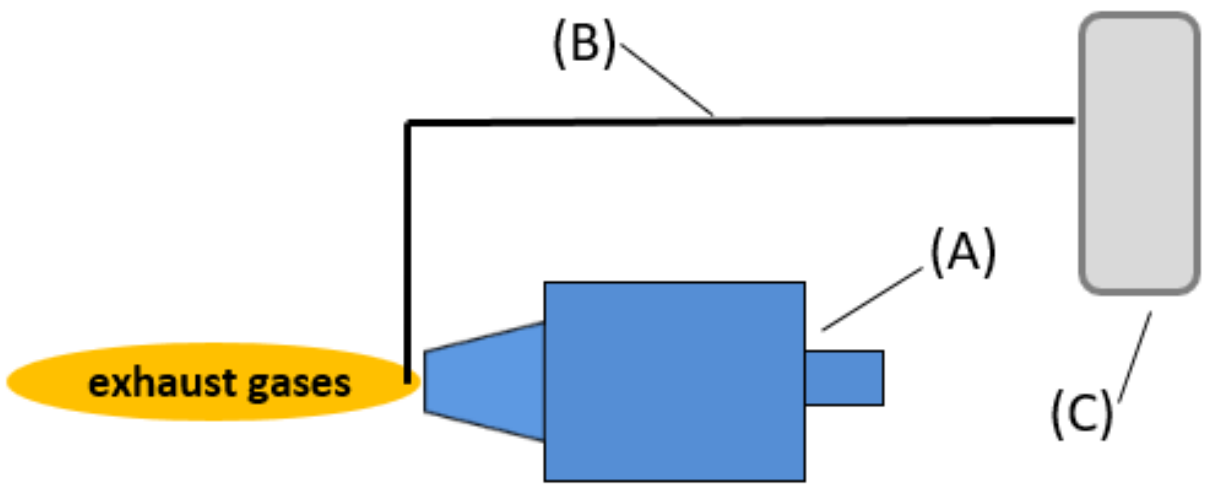

Figure 1. Test rig (A)—miniature test engine, (B)—exhaust pipe, (C)—exhaust gas collection and storage system.

Table 1. Technical parameters of GTM-140 engine.

\begin{tabular}{cc}
\hline Parameters & Descriptions \\
\hline type of engine & Turbojet-single spool \\
\hline compressor & single stage radial compressor \\
\hline combustion chamber & annular combustion chamber \\
\hline turbine & single stage axial flow turbine \\
\hline rpm & $33,000-120,000$ \\
\hline max. thrust & $140 \mathrm{~N}$ \\
\hline fuel consumption at max. rpm & $420 \mathrm{~g} / \mathrm{min}$ \\
\hline mass flow at max. rpm & $350 \mathrm{~g} / \mathrm{s}$ \\
\hline max. exhaust gas temperature & $750{ }^{\circ} \mathrm{C}$ \\
\hline
\end{tabular}

The presented GTM-140 engine is an main element of the Miniature Jet Engine Test Rig (MiniJETRig), built in Air Force Institute of Technology in Poland. The construction and research capabilities of the engine rig are described by Gawron and Białecki in [18]. Information on the applied measuring sensors regarding basic operating parameters together with their accuracy is presented in [19].

MiniJETRig besides turbojet engine is equipped with two analyser: portable exhaust analyser and particulate matter analyser. The test rig has a control system with data acquisition based on the measurement cards. The operating speed of a miniature GTM140 turbojet engine is $33,000-120,000 \mathrm{rpm}$ and its maximum thrust is $140 \mathrm{~N}$. The engine the engine is built based on single-stage radial compressor, a single-stage axial turbine and an annular combustion chamber (with vaporizer tubes). Engine is started via an automatic electric starter. It is also possible to start the engine pneumatically which enables it additionally air mass flow rate measurement. The engine's fuel supply system was modified by splitting subsystem of supplying fuel to the combustion chamber and bearings lubrication subsystem. This solution enables the combustion of tested fuel in engine without oil component.

MiniJETRig is used for the research on jet fuel combustion process. The results of previous work carried out on this rig were presented in papers [20-23]. The work included research on blends of petroleum jet fuel with synthetic components from two synthetic hydrocarbon production technologies: HEFA and ATJ. The purpose of the research was 
to analyse the effect of the addition of a component to Jet A- 1 fuel on the engine performance characteristics and the characteristics of the emissions of exhaust gaseous exhaust components.

The tests were carried out for all test fuels according to the same sample profile (Figure 2). Two independent tests were performed for each fuel. After starting the engine on a given fuel, the rotational speed was gradually increased. It was assumed beforehand that measurements would take place at one selected engine performance condition, i.e., $62,000 \mathrm{rpm}$. The choice was dictated by the fact that this speed corresponds to approx. $30 \%$ of the value of the maximum thrust force for a miniature turbojet engine. The $30 \%$ thrust value occurs during the certification procedure in the field of gaseous emissions from aircraft turbine engines [24].

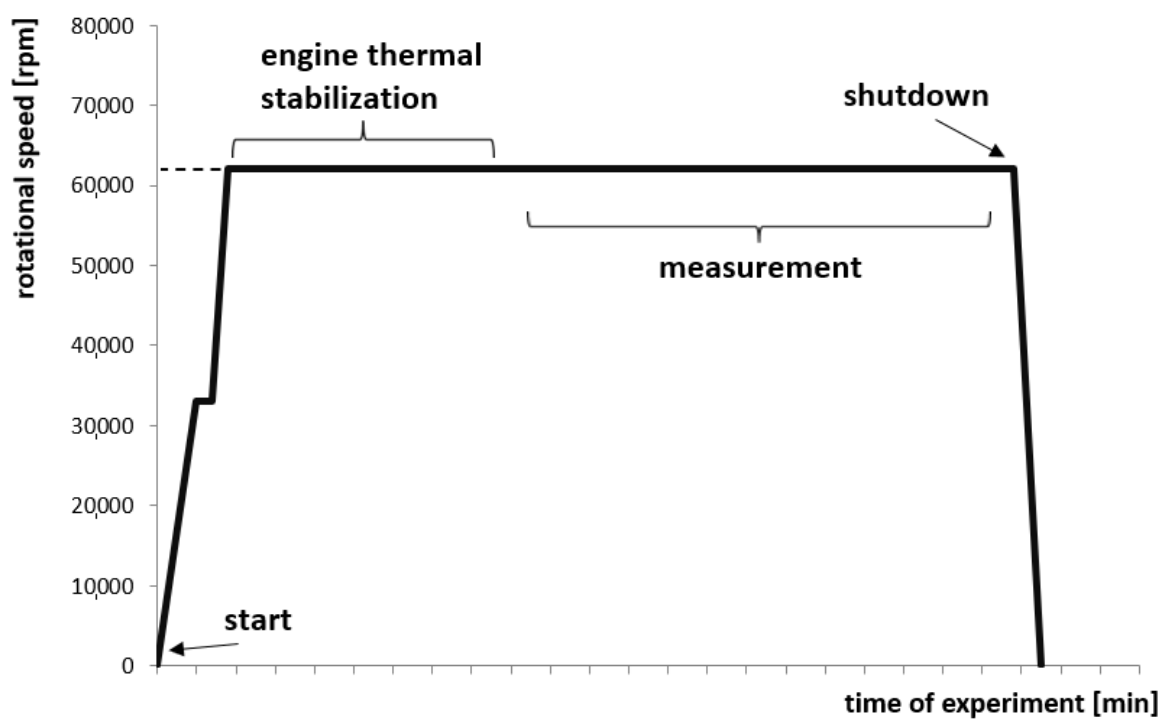

Figure 2. Engine test profile during dynamometer tests.

After reaching a predetermined rotational speed, the period of $30 \mathrm{~s}$ was waited in each case for the thermodynamic state of the engine, and thus the combustion process, to stabilise. After this time, the actual measurement began, consisting of the collection of the exhaust gases into a properly prepared system containing Tedlar bags (Figure 3). The test material (exhaust gases) collected in this way was then used to determine the volatile organic compounds. During the tests the basic parameters of engine performance were also recorded: engine thrust (strain gauge bar), rotational speed (optical sensor) and temperature behind the turbine (k-type thermocouple).

The concentration of volatile organic compounds in the samples was evaluated with the aid of gas chromatography according to the Emission Research Laboratory Test Procedure No. 1/2010, using a Varian 450-GC gas chromatograph. The chromatograph was equipped with a flame ionization detector (FID), and a column Varian VF-WAXms $30 \mathrm{~m} \times 0.25 \mathrm{~mm}$ ID, DF $0.25 \mathrm{um}$. The temperature at the column was $373 \mathrm{~K}, 523 \mathrm{~K}$ at the dispenser and $423 \mathrm{~K}$ and the detectors. The samples were collected with YEARS aspirator whose flow rate was adjusted to $30 \mathrm{dm}^{3} / \mathrm{h}$. Each time the $10 \mathrm{dm}^{3}$ of exhaust gases was aspirated. The gas was adsorbed on active carbon Anasorb ${ }^{\circledR}$ SKC CSC with volume of $5 \mathrm{~cm}^{3}$. Extraction proceeded for $20 \mathrm{~min}$. During the test an adequat mixing of the material was ensured. Then $5 \mu \mathrm{L}$ of the solution was drawn from above the carbon layer. The collected sample was injected into the chromatograph. The total relative error of the method was estimated at $20 \%$ [25]. 


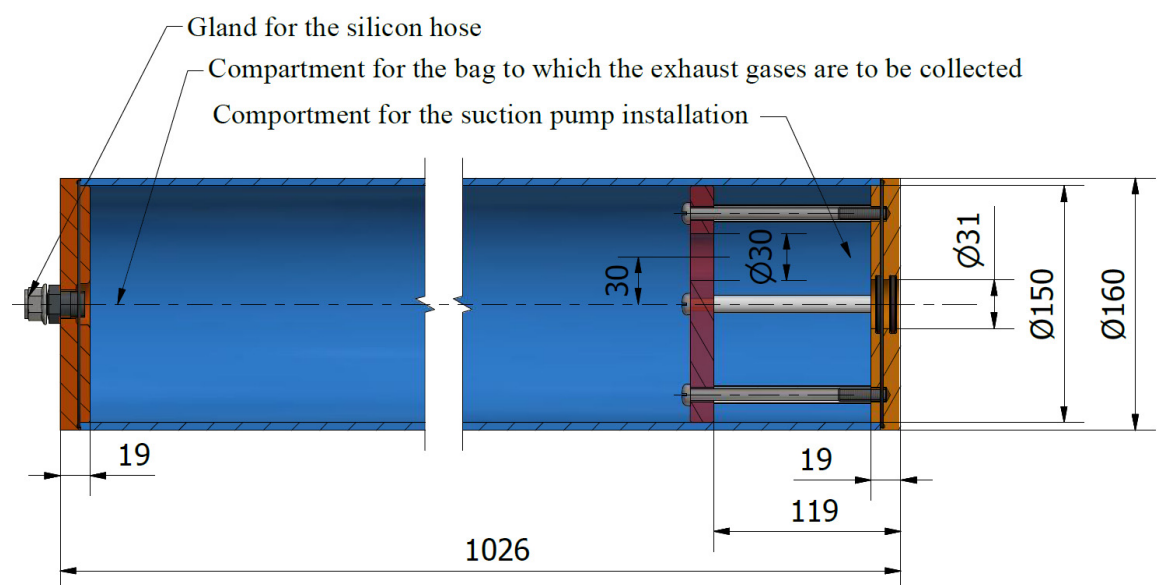

(a)

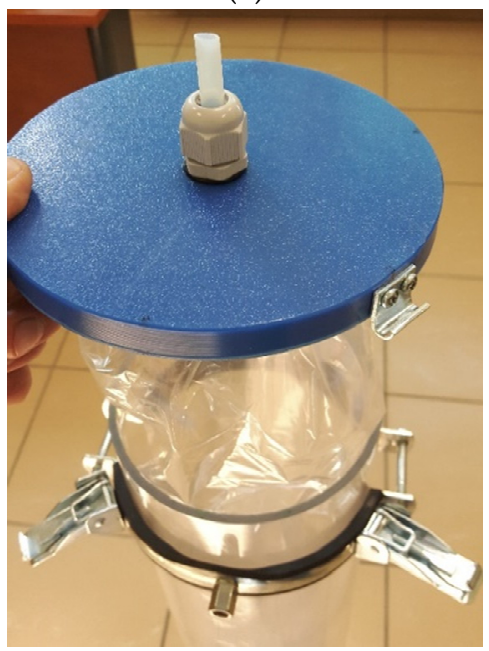

(b)

Figure 3. Exhaust gas collection and storage system: (a) technical diagram; (b) illustrative photograph.

The identification of VOCs is usually performed in three steps: collection of samples, desorption and chemical analysis. In order to identify VOCs and their concentrations, a special probe was placed directly in the exhaust gases, samples of the latter were aspirated and subjected to chromatographic tests.

Engine tests were conducted on selected fuels:

- $\quad$ pure Jet A-1 fuel-Jet designation;

- blends of Jet A-1 with a HEFA technology component (used cooking oil feedstock) in concentrations of: $25 \%, 50 \%, 75 \%$ share $(v / v)$ of the biocomponent-designation JetX/HEFAX, where $X$ stands for the specific concentration of the given component.

Selected physicochemical properties of test fuels are presented in Table 2. As the biocomponent share in the blend with jet fuel increases, the density of such a blend decreases with simultaneous increase of kinematic viscosity. On the other hand, the parameter-net heat of combustion, which is directly related to the process of fuel combustion, increases with increasing biocomponent share. This may translate into higher combustion heat generated during operation of a turbine engine and higher temperature obtained in the combustion chamber. The neat biocomponent does not contain aromatics; the aromatic content in the blend comes only from the fossil jet fuel. Moreover, the content of aromatics in fuel is undesirable due to its negative impact on the clean of the combustion process. On the other hand, the content of aromatics is important for ensuring an appropriate sealing function in aircraft fuel systems and installations [26]. 
Table 2. Selected physicochemical properties of Jet A-1, HEFA component and their blends.

\begin{tabular}{|c|c|c|c|c|c|c|c|c|}
\hline Lp. & Property Name & $\begin{array}{c}\text { Unit of } \\
\text { Measurement }\end{array}$ & $\begin{array}{l}\text { Testing } \\
\text { Method }\end{array}$ & Jet & $\begin{array}{c}\text { Jet75/ } \\
\text { HEFA25 }\end{array}$ & $\begin{array}{c}\text { Jet50/ } \\
\text { HEFA50 }\end{array}$ & $\begin{array}{c}\text { Jet25/ } \\
\text { HEFA75 }\end{array}$ & HEFA \\
\hline 1. & Density at $15^{\circ} \mathrm{C}$ & $\mathrm{kg} / \mathrm{m}^{3}$ & ASTM D 4052 & 789.3 & 779.8 & 770.7 & 761.4 & 751.9 \\
\hline 2. & Viscosity at $-20^{\circ} \mathrm{C}$ & $\mathrm{mm}^{2} / \mathrm{s}$ & ASTM D 445 & 2.998 & 3.227 & 3.481 & 3.754 & 4.077 \\
\hline 3. & $\begin{array}{l}\text { Net heat of } \\
\text { combustion }\end{array}$ & $\mathrm{MJ} / \mathrm{kg}$ & ASTM D 3338 & 43.312 & 43.542 & 43.741 & 43.948 & 44.172 \\
\hline 4. & Aromatics & $\%(v / v)$ & ASTM D 1319 & 15.1 & 11.0 & 7.2 & 4.0 & 0 \\
\hline
\end{tabular}

\section{Results and Discussion}

As regards engine operating parameters, the results are presented in Table 3. Engine tests for each fuel were performed twice. The table shows the average values of a given parameter for a given engine test.

Table 3. Engine operating parameters during tests with different fuels.

\begin{tabular}{cccc}
\hline Fuel & Rotational Speed $[\mathbf{r p m}]$ & Engine Thrust $[\mathbf{N}]$ & Temperature behind the Turbine $\left[{ }^{\circ} \mathbf{C}\right]$ \\
\hline Jet & 62,148 & 40.6 & 510 \\
\hline Jet75/HEFA25 & 62,075 & 40.6 & 509 \\
\hline Jet50/HEFA50 & 62,658 & 42.7 & 508 \\
\hline Jet25/HEFA75 & 62,730 & 41.3 & 509 \\
\hline
\end{tabular}

On the basis of the presented results, it can be seen that for all tested fuels the engine operated in a comparable range. Similar values of rotational speed, engine thrust and temperature behind the turbine were obtained. During the tests, no fuel consumption was measured that could show differences between the tested fuels related to the influence of both density and neat heat of combustion of a given fuel.

The measured concentration values of volatile organic compounds in the exhaust gases emitted by the GTM-140 miniature engine are shown in Figure 4. The main focus here is on the compounds from the BTX group-i.e., benzene, toluene and xylenes, due to their highest harmfulness among the identified compounds. The most harmful of the BTXs is benzene. In this case, it turns out that the more HEFA component a fuel blend contains, the lower benzene concentrations are obtained. On the other hand, it can be observed that the concentration of toluene and xylene tends to increase with increasing share of the component in the mixture. Nevertheless, the decreasing trend of benzene is dominant here. The aggregate comparison of BTX (orange colour in the graph) also shows a decreasing trend in the harmfulness of the emitted exhaust gases from the miniature engine with an increasing share of the synthetic component in the tested fuel blends.

The effect of fuel blend composition on VOC emissions is presented as the utility profile. This makes it possible to determine the optimum blend composition, in which exhaust toxicity is minimised by minimising the concentration of BTX, while maintaining comparable engine performance. Additionally, it is possible to observe the general effect of fuel composition change on each of the individual parameters measured [27].

Benzene has the highest concentration (Figure 4) compared to other compounds, therefore it was concluded that the concentration of this parameter would be the most representative in the BTX group. Xylenes consist of m-xylene, o-xylene and p-xylene. The concentrations of these compounds were summed and presented as xylenes.

The utility profile is shown in Figure 5. Utility has been coded from 0 to 1 , with 0 being considered undesirable and 1 being high, desirable utility. Therefore, in the graph, a high BTX concentration is assigned the utility value of 0 and a low concentration is assigned the high utility (i.e., utility of 1). By analysing the profiles, it can be concluded that the optimal blend of Jet A-1 fuel with HEFA synthetic component consists of a share $(v / v)$ of $62.5 \%$ fossil fuel and $37.5 \%$ of HEFA component. In this case, the overall utility was 0.70767 . 


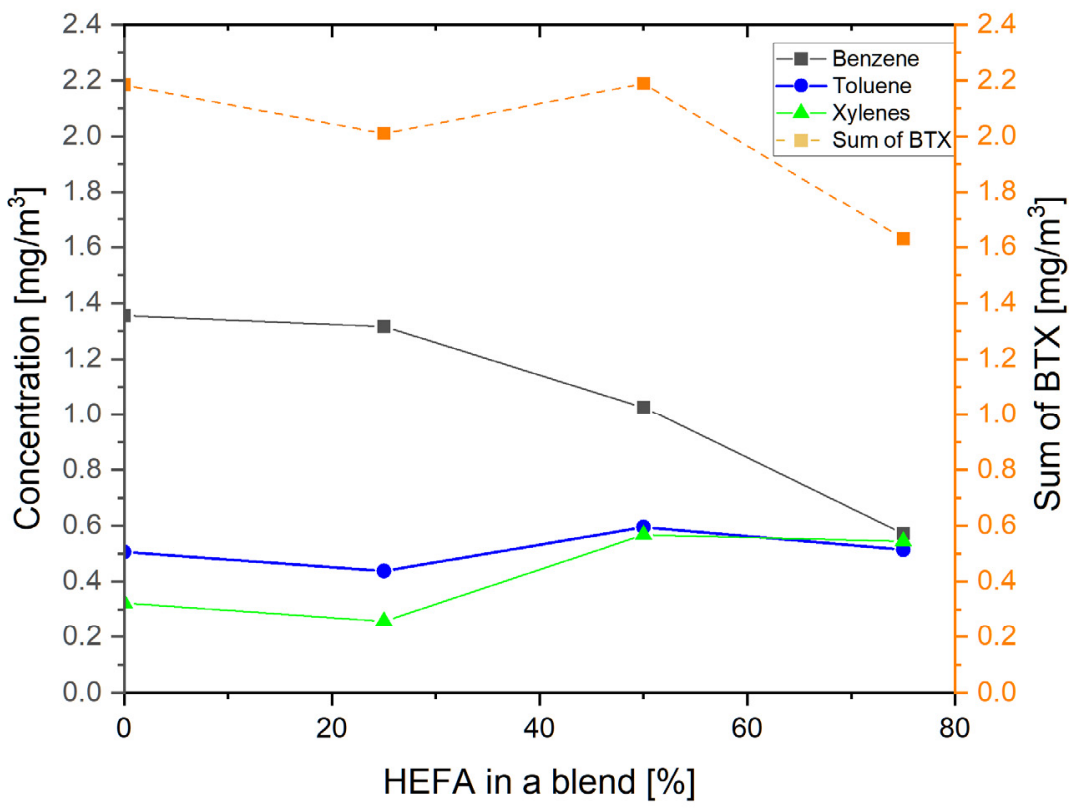

Figure 4. Emission of volatile organic compounds depending on the share of the synthetic component in the tested fuel blend.
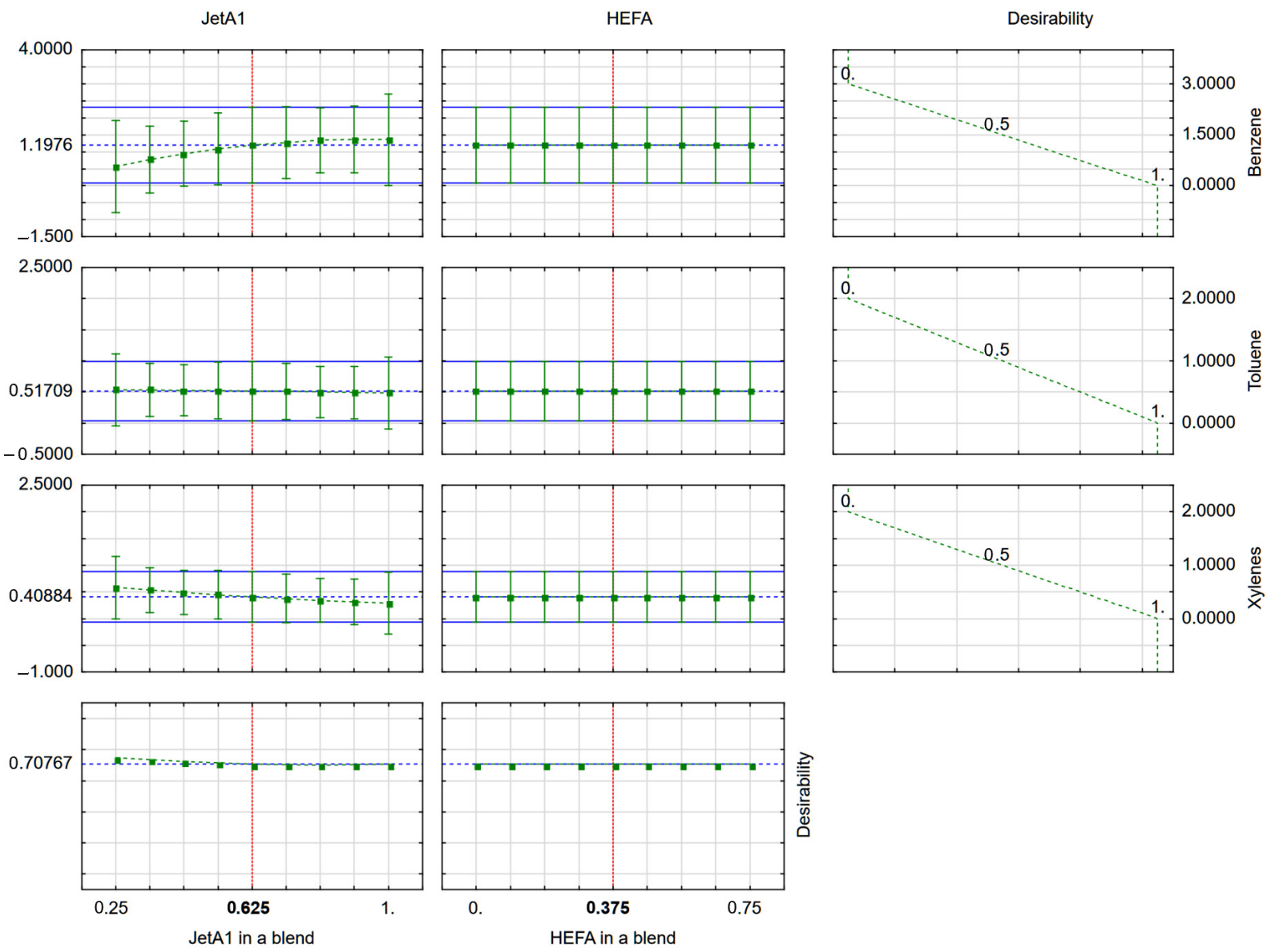

Figure 5. Desirability function determining the effect of BTX compounds on the fuel blend contents. 


\section{Conclusions}

In this study, emissions of volatile organic compounds from the miniature turbojet engine were analysed. Research was conducted using synthesized hydrocarbons from HEFA technology. Blends of Jet A-1 fuel with the synthetic component HEFA at different concentration ratios were analysed. All the test results were compared with the neat Jet A-1 fuel.

The main conclusions can be summarized as follows:

- The use of a miniature turbine jet engine for testing the exhaust gas composition, including the assessment of volatile organic compound emissions, gives great benefits related to the possibility of planning much wider tests than in the case of full-scale turbine engine tests.

- In the performance analysis of the miniature jet engine, no significant differences were observed for all test fuels. After reaching the predetermined speed, the engine powered by different fuels generated similar thrust and temperature behind the turbine.

- As regards the emissions of volatile organic compounds in exhaust gases, the focus was on the most harmful compounds-the BTX group (benzene, toluene and xylene). Among this group of compounds, the highest concentrations were recorded for benzene.

- As the proportion of HEFA component in the blend increases, the concentration of benzene shows a decreasing trend, while the concentration of toluene and xylenes does not show an unequivocal tendency.

- The developed utility profile indicates that the most optimal, i.e., the least toxic in terms of exhaust gases (minimising the BTX concentration) is a blend with a share $(v / v)$ of $62.5 \%$ fossil fuel and $37.5 \%$ of HEFA component.

- The next stage of research, planned for the near future, involves testing alternative fuels with regards to VOC emissions using a miniature jet engine at several engine operating modes, i.e., several rotational speed ranges.

Author Contributions: Conceptualization, B.G. and A.G.; methodology, B.G. and A.G.; investigation, B.G., A.G. and R.W.; data analysis, B.G., A.G., A.W. and J.M.; writing—original draft preparation, B.G. and A.G.; writing-review and editing, A.J. and T.B.; visualization, B.G. and A.G.; supervision, A.J., T.B., M.Z.; resources, B.G. and A.G. All authors have read and agreed to the published version of the manuscript.

Funding: This research received no external funding.

Institutional Review Board Statement: Not applicable.

Informed Consent Statement: Not applicable.

Data Availability Statement: Data sharing not applicable.

Acknowledgments: The research was carried out using the R\&D infrastructure of the project: Complex GEO-3EM ENERGY ECOLOGY EDUCATION.

Conflicts of Interest: The authors declare no conflict of interest.

\section{References}

1. ASTM D7566. Standard Specification for Aviation Turbine Fuel Containing Synthesized Hydrocarbons; ASTM International: West Conshohocken, PA, USA, 2019.

2. Dyrektywa 2004/42/We Parlamentu Europejskiego I Rady Z Dn. W Sprawie Ograniczeń Emisji Lotnych ZwiąZków Organicznych W Wyniku Stosowania Rozpuszczalników Organicznych W Niektórych Farbach I Lakierach Oraz W Preparatach Do Odnawiania Pojazdów. Available online: https:/ / eur-lex.europa.eu/legal-content/PL/TXT/PDF/?uri=CELEX:32004L0042\&from=PT (accessed on 21 April 2004).

3. Kęska, A.; Janicka, A. Determination of volatile organic compounds for combustion engines compliant with Euro 4 and Euro 6. Proc. ECOpole 2017, 11, 387-394.

4. Lebrecht, G.; Czerczak, S.; Szymczak, W. Benzen. Dokumentacja proponowanych wartości dopuszczalnych poziomów narażenia zawodowego. Podstawy Metod. Oceny Sr. Pr. 2003, 1, 5-60. 
5. Kruczyński, S.W.; Merkisz, J.; Ślęzak, M. Zanieczyszczenie Powietrza Spalinami Przez Transport Samochodowy; Wydawnictwo Komunikacji i Łączności: Warsaw, Poland, 2019; pp. 1-515.

6. Herndon, S.C.; Wood, E.C.; Northway, M.J.; Miake-Lye, R.; Thornhill, L.; Beyersdorf, A.; Anderson, B.E.; Dowlin, R.; Dodds, W.; Knighton, W.B. Aircraft hydrocarbon emissions at Oakland International Airport. Environ. Sci. Technol. 2009, 43, $1730-1736$. [CrossRef] [PubMed]

7. Beyersdorf, A.J.; Thornhill, K.L.; Winstead, E.L.; Ziemba, L.D.; Blake, D.R.; Timko, M.T.; Anderson, B.E. Power-dependent speciation of volatile organic compounds in aircraft exhaust. Atmos. Environ. 2012, 61, 275-282. [CrossRef]

8. Williams, P.I.; Allan, J.D.; Lobo, P.; Coe, H.; Christie, S.; Wilson, C.; Hagen, D.; Whitefield, P.; Raper, D.; Rye, L. Impact of Alternative Fuels on Emissions Characteristics of a Gas Turbine Engine-Part 2: Volatile and Semivolatile Particulate Matter Emissions. Environ. Sci. Technol. 2012, 46, 10812-10819. [CrossRef] [PubMed]

9. Cross, E.S.; Hunter, J.F.; Carrasquillo, A.J.; Franklin, J.P.; Herndon, S.C.; Jayne, J.T.; Worsnop, D.R.; Miake-Lye, R.C.; Kroll, J.H. Online measurements of the emissions of intermediate-volatility and semi-volatile organic compounds from aircraft. Atmos. Chem. Phys. 2013, 13, 7845-7858. [CrossRef]

10. Andoga, R.; Főző, L.; Schrötter, M.; Szabo, S. The Use of Ethanol as an Alternative Fuel for Small Turbojet Engines. Sustainability 2021, 13, 2541. [CrossRef]

11. Boomadevi, P.; Paulson, V.; Samlal, S.; Varatharajan, M.; Sekar, M.; Alsehli, M.; Elfasakhany, A.; Tola, S. Impact of microalgae biofuel on microgas turbine aviation engine: A combustion and emission study. Fuel 2021, 302, 121155. [CrossRef]

12. Suchocki, T.; Witanowski, L.; Lampart, P.; Kazimierski, P.; Januszewicz, K.; Gawron, B. Experimental investigation of performance and emission characteristics of a miniature gas turbine supplied by blends of kerosene and waste tyre pyrolysis oil. Energy 2021, 215, 119125. [CrossRef]

13. Manigandana, S.; Atabani, A.E.; Ponnusamy, V.K.; Gunasekar, P. Impact of additives in Jet-A fuel blends on combustion, emission and exergetic analysis using a micro-gas turbine engine. Fuel 2020, 276, 118104. [CrossRef]

14. Janicka, A.; Zawiślak, M.; Zaczyńska, E.; Czarny, A.; Górniak, A.; Gawron, B.; Białecki, T. Exhausts toxicity investigation of turbojet engine, fed with conventional and biofuel, performed with aid of BAT-CELL method. Toxicol. Lett. 2017, 280 (Suppl. S1), S202. [CrossRef]

15. Gawron, B.; Białecki, T.; Górniak, A.; Janicka, A.; Zawiślak, M. An innovative method for exhaust gases toxicity evaluation in the miniature turbojet engine. Aircr. Eng. Aerosp. 2017, 89, 757-763. [CrossRef]

16. Gawron, B.; Białecki, T.; Janicka, A.; Zawiślak, M.; Górniak, A. Exhaust toxicity evaluation in a gas turbine engine fueled by aviation fuel containing synthesized hydrocarbons. Aircr. Eng. Aerosp. 2020, 92, 60-66. [CrossRef]

17. Janicka, A.; Zawiślak, M.; Gawron, B.; Górniak, A.; Białecki, T. Emission of volatile organic compounds during combustion process in a miniature turbojet engine. Environ. Prot. Eng. 2018, 44, 57-67. [CrossRef]

18. Gawron, B.; Białecki, T. The laboratory test rig with miniature jet engine to research aviation fuels combustion process. J. Konbin 2015, 36, 79-90. [CrossRef]

19. Gawron, B.; Białecki, T. Measurement of exhaust gas emissions from miniature turbojet engine. Combust. Engines 2016, 167, 58-63. [CrossRef]

20. Białecki, T.; Dziegielewski, W.; Kowalski, M.; Kulczycki, A. Reactivity Model as a Tool to Compare the Combustion Process in Aviation Turbine Engines Powered by Synthetic Fuels. Energies 2021, 14, 6302. [CrossRef]

21. Gawron, B.; Białecki, T. Impact of a Jet A-1/HEFA blend on the performance and emission characteristics of a miniature turbojet engine. Int. J. Environ. Sci. Technol. 2018, 15, 1501-1508. [CrossRef]

22. Gawron, B.; Białecki, T.; Janicka, A.; Suchocki, T. Combustion and emissions characteristics of the turbine engine fueled with HEFA blends from different feedstocks. Energies 2020, 13, 1277. [CrossRef]

23. Przysowa, R.; Gawron, B.; Białecki, T.; Łęgowik, A.; Merkisz, J.; Jasiński, R. Performance and emissions of a microturbine and turbofan powered by alternative fuels. Aerospace 2021, 8, 25. [CrossRef]

24. International Standards and Recommended Practice. Annex 16 Vol II, Environmental Protection-Volume II Aircraft Engine Emissions; International Civil Aviation Organization (ICAO): Montreal, QC, Canada, 2017.

25. PKN. Powietrze Wnętrz, Atmosferyczne i na Stanowiskach Pracy-Pobieranie Próbek I Analiza Lotnych ZwiąZków Organicznych Z Wykorzystaniem Rurki Sorpcyjnej/Desorpcji Termicznej/Kapilarnej Chromatografii Gazowej-Część 1: Aspiracyjne Pobieranie Próbek; PN-EN ISO16017-1:2006; PKN: Warszawa, Poland, 2006.

26. Białecki, T.; Gawron, B.; Giemza, B.; Głąb, J. Influence of synthetic fuel on nitrile rubbers used in aviation. Transp. Probl. 2020, 15, 29-41. [CrossRef]

27. Sroka, Z.J.; Ahmed, H.; Sitnik, L.; Górniak, A.; Skrętowicz, M.D.; Magdziak-Tokłowicz, M. Prediction of Ternary Gasoline Composition Using Light and Heavy Alcohols to Reduce Fuel Consumption and Meet Emission Standards. SAE Tech. Pap. 2020, $1,1-13$. 